\title{
PELATIHAN PENYUSUNAN TATA KERJA DAN ANALISIS EVALUASI PROGRAM KEGIATAN SEKOLAH
}

\author{
Sofyan, Bradley Setiyadi*, Harlina Harja, Siti Rahma Sari \\ Universitas Jambi, Indonesia \\ *bradleysetiyadi@unja.ac.id
}

\begin{abstract}
The implementation of activities carried out by schools should be based on existing work procedures. From here the management functions play a role, namely planning, organizing, implementing and finally evaluating. Every activity program that is carried out should have carried out an evaluation activity to see the extent of the benefits of an activity program along with its shortcomings and obstacles. The arrangement of school work procedures is a step to make a plan for school activity programs. In addition, the preparation of school work procedures is also a work procedure for every school member in carrying out work according to their duties, principal and functions. The evaluation analysis of the school activity program is a control effort to see how many school activity programs are carried out and their benefits for the development of the school. Evaluation is an improvement and refinement as well as an assessment of whether a school activity program can be continued or not. The Training of Work Arrangement and School Evaluation Analysis is considered important in order to improve school performance which also affects the improvement of the quality of education. The end result of this service will be very useful for policy makers in improving school performance.
\end{abstract}

Keywords: working procedure, evaluation, school performance

\begin{abstract}
Abstrak
Penyelenggaraan kegiatan-kegiatann yang dilakukan oleh sekolah sudah semestinya didasarkan pada tata kerja yang ada. Dari sini berperan fungsi-fungsi manajemen yaitu perencanaan, pengorganisasian, pelaksanaan dan terakhir evaluasi. Setiap program kegiatan yang dilaksanakan sudah semestinya dilakukan kegiatan evaluasi untuk melihat sejauh mana manfaat suatu program kegiatan beserta kekurangan-kekurangan dan hambatan-hambatan yang ada. Penyusunan tata kerja sekolah merupakan langkah untuk membuat suatu perencanaan terhadap program-program kegiatan sekolah. Selain itu, penyusunan tata kerja sekolah juga merupakan prosedur kerja bagi setiap warga sekolah dalam melaksanakan pekerjaan sesuai tugas, pokok dan fungsinya. Analisis evaluasi terhadap program kegiatan sekolah merupakan upaya kontrol untuk melihat sejuah mana program kegiatan sekolah dijalankan serta manfaatnya bagi perkembangan sekolah tersebut. Evaluasi merupakan sebuah perbaikan dan penyempurnaan serta penilaian apakah suatu program kegiatan sekolah dapat diteruskan atau tidak perlu dilanjutkan. Pelatihan Penyusunan Tata Kerja dan Analisis Evaluasi Sekolah ini dipandang penting dalam rangka meningkatkan kinerja sekolah yang juga berpengaruh pada peningkatan mutu pendidikan. Hasil akhir dari pengabdian ini akan sangat berguna bagi pengambil kebijakan dalam meningkatkan kinerja sekolah.
\end{abstract}

Kata Kunci: tata kerja, evaluasi, kinerja sekolah

Submitted: 2020-09-09 Revised: $2020-09-21$ Accepted: $2020-09-25$

\section{Pendahuluan}

Tugas, pokok dan fungsi warga sekolah, baik pimpinan sekolah, guru dan staf didasarkan pada tata kerja sekolah yang merupakan penjabaran dari struktur organisasi sekolah. Tata kerja disusun supaya tidak terjadi tumpang tindih perkerjaan dan kewenangan. Selain itu, tata kerja juga menjadi acuan dalam pelaksanaan kegiatan- 
kegiatan yang diselenggarakan sekolah. Dalam tata kerja, prosedur kerja, dan sistem kerja harus disusun untuk memiliki sifat stabilitas dan fleksibilitas. Stabilitas disini maksudnya adalah bahwa tata, prosedur, dan sistem kerja itu harus mengandung unsur tetap sehingga menjamin kelancaran dan kemantapan kerja, sehingga suatu pekerjaan tidak berubah-ubah tata kerjanya. Fleksibilitas artinya bahwa dalam pelaksanaannya tidak kaku tetapi harus luwes yaitu masih memungkinkan diadakannya saling pergantian tugas, dan tugasnya dapat berubah-ubah pada setiap saat, tergantung dari sistem kerja itu sendiri. Tata kerja membuat pekerjaan menjadi terstruktur dan terorganisir dengan baik agar lebih mudah disesuaikan dengan keadaan yang sering berubah sehingga kegiatan yang dilaksanakan dapat berjalan dengan baik dan lancar.

Tata kerja adalah cara-cara pelaksanaan kerja yang seefisien mungkin atas sesuatu tugas dengan mengingat segi-segi tujuan, peralatan, fasilitas, tenaga kerja, waktu, ruang dan biaya yang tersedia sedangkan Prosedur Kerja adalah rangkaian tata kerja yang berkaitan satu sama lain sehingga menunjukkan adanya suatu urutan tahap demi tahap serta jalan yang harus ditempuh dalam rangka penyelesaian sesuatu bidang tugas. Sementara sistem kerja adalah suatu jaringan kerja yang terdiri atas bermacam- macam prosedur yang merupakan kesatuan yang bulat yang tampak dalam operasi pekerjaan. (Warsidi, 2000:35). Tata kerja berkaitan dengan SOP atau Standar Operasional Prosedur yang merupakan panduan untuk memastikan kegiatan operasional organisasi berjalan dengan lancar (Sailendra, 2015:14). SOP adalah dokumen yang berkaitan dengan prosedur yang dilakukan secara kronologis untuk menyelesaikan suatu pekerjaan yang bertujuan untuk memperoleh hasil kerja yang paling efektif dari para pekerja dengan biaya yang serendah-rendahnya. SOP terdiri dari manfaat, kapan dibuat atau direvisi, metode penulisan prosedur, serta dilengkapi oleh bagan flowchart di bagian akhir. SOP adalah sistem yang disusun untuk memudahkan, merapihkan dan menertibkan pekerjaan. Sistem ini berisi urutan proses melakukan pekerjaan dari awal sampai akhir. (Laksmi, 2008:52).

Evaluasi program merupakan suatu metode untuk mengetahui kinerja suatu program dengan membandingkan dengan kriteria yang telah ditentukan atau tujuan yang ingin dicapai dengan hasil yang dicapai. Hasil yang dicapai dalam bentuk informasi digunakan sebagai bahan pertimbangan untuk pembuatan keputusan dan penentuan kebijakan. Evaluasi ini dilakukan secara sistematis dengan melalui proses pengumpulan dan analisis data yang dapat dipertanggungjawabkan kebenarannya, untuk mengetahui tingkat keberhasilan suatu program. (Lazwardi, 2017:155). Evaluasi program adalah upaya mengumpulkan informasi mengenai suatu program, kegiatan atau proyek. Informasi tersebut berguna untuk mengambil keputusan, antara lain untuk memperbaiki program, menyempurnakan kegiatan program lanjutan, menghentikan suatu kegiatan atau menyebarluaskan gagasan yang mendasari suatu program atau kegiatan. (Sudjana, 2006:20-21). Dalam kaitannya dengan program pendidikan, evaluasi adalah suatu proses yang menentukan sampai sejauh mana tujuan pendidikan dapat dicapai. Evaluasi pendidikan merupakan proses mendeskripsikan, mengumpulkan dan menyajikan informasi yang berguna untuk menentapkan alternatif keputusan. Evaluasi juga bisa dianggap sebagai perbedaan apa yang ada dengan suatu standar untuk mengetahui apakah ada selisih. (Tayipnapis, 2008:3). 
Sejauh ini terdapat berbagai kekurangan dalam penyusunan tata kerja sekolah dan analisis evaluasi program kegiatan sekolah. Hal ini menyebabkan pekerjaan yang dilakukan oleh warga sekolah, baik itu pimpinan sekolah, pendidik dan tenaga kependidkan seringkali tidak sesuai dengan strukturn sekolah yang ada. Hal itu berdampak pada program kegiatan yang dilakukan sekolah, yang berjalan hanya untuk memenuhi kewajiban namun tidak adanya kontroldan evaluasi, sehingga programprogram yang dijalankan cenderung kurang memberikan manfaat yang nyata bagi sekolah.

Penyusunan tata kerja sekolah merupakan langkah untuk membuat suatu perencanaan terhadap program-program kegiatan sekolah. Selain itu, penyusunan tata kerja sekolah juga merupakan prosedur kerja bagi setiap warga sekolah dalam melaksanakan pekerjaan sesuai tugas, pokok dan fungsinya. Analisis evaluasi terhadap program kegiatan sekolah merupakan upaya control untuk melihat sejuah mana program kegiatan sekolah dijalankan serta manfaatnya bagi perkembangan sekolah tersebut. Evaluasi merupakan sebuah perbaikan dan penyempurnaan serta penilaian apakah suatu program kegiatan sekolah dapat diteruskan atau tidak perlu dilanjutkan.

\section{Metode}

Sasaran latih dari program Pelatihan Penyusunan Tata Kerja dan Analisis Program Kegiatan Sekolah adalah pendidik dan tenaga kependidikan di SMK Negeri 1 Kerinci yang memiliki karakteristik sebagai berikut:

1. Kepala sekolah beserta wakil-wakilnya.

2. Guru yang mendapat tugas tambahan mengelola kegiatan.

3. Staf tata usaha

Materi Pelatihan Penyusunan Tata Kerja dan Analisis Program Kegiatan Sekolah mencakup pembelajaran yang mendorong peningkatan kinerja sekolah melalui penyusunan tata kerja sekolah dan evaluasi program kegiatan sekolah

Tabel 1. Materi dan Alokasi Waktu Pelatihan

\begin{tabular}{|c|c|c|c|c|c|c|c|}
\hline \multirow[t]{2}{*}{ No } & \multirow{2}{*}{\multicolumn{2}{|c|}{ Materi Pelatihan }} & \multicolumn{2}{|c|}{ Alokasi } & Instruktur & \multirow{2}{*}{\multicolumn{2}{|c|}{ Tempat }} \\
\hline & & & Teori & Praktek & & & \\
\hline 1 & $\begin{array}{l}\text { Pelatihan Pe } \\
\text { Tata Kerja Seko }\end{array}$ & $\begin{array}{l}\text { Tyusunan } \\
\text { lah }\end{array}$ & $2 \mathrm{JP}$ & $7 \mathrm{JP}$ & Dr. Sofyan, S.Pd., M.Pd & $\begin{array}{l}\text { SMK Negeri } \\
\text { Kerinci }\end{array}$ & 1 \\
\hline 2 & $\begin{array}{l}\text { Pelatihan } \\
\text { Penyempurnaan } \\
\text { Sekolah }\end{array}$ & SOP & $2 \mathrm{JP}$ & $7 \mathrm{JP}$ & $\begin{array}{l}\text { Bradley Setiyadi, S.Pt., } \\
\text { M.Pd }\end{array}$ & $\begin{array}{l}\text { SMK Negeri } 1 \\
\text { Kerinci }\end{array}$ & \\
\hline 3 & $\begin{array}{l}\text { Pelatihan } \\
\text { Program } \\
\text { Sekolah }\end{array}$ & $\begin{array}{l}\text { Evaluasi } \\
\text { Kegiatan }\end{array}$ & $2 \mathrm{JP}$ & $7 \mathrm{JP}$ & $\begin{array}{l}\text { Dr. Harlina Harja, M.Pd } \\
\text { dan Dr. Siti Rahma Sari, } \\
\text { M.Pd }\end{array}$ & $\begin{array}{l}\text { SMK Negeri } 1 \\
\text { Kerinci }\end{array}$ & \\
\hline
\end{tabular}

Narasumber yang akan memberikan pelatihan Penyusunan Tata Kerja dan Analisis Evaluasi Program Kegiatan Sekolah telah memenuhi kriteria sebagai berikut:

1. Memiliki kompetensi dalam mendidik orang dewasa

2. Memiliki etos kerja dan tanggung jawab yang dapat dijadikan panutan bagi peserta latih

3. Diutamakan yang memiliki pengalaman belajar baik secara teoritis maupun praktis 
Subjek dari pengabdian Pelatihan Penyusunan Tata Kerja dan Analisis Evaluasi Program Kegiatan Sekolah adalah pimpinan sekolah, pendidik dan tenaga kependidikan. Pelatihan Penyusunan Tata Kerja dan Analisis Evaluasi Program Kegiatan Sekolah akan dilakukan dengan mengunakan berbagai metode yang terdiri dari ceramah, diskusi kelompok besar dan kecil, presentasi individu dan kelompok. Dalam pelatihan ini, semua peserta akan dilatih baik berkerja secara individu maupun secara kelompok. Metode ceramah akan digunakan untuk memberikan pengarahan kepada peserta hal-hal yang berhubungan dengan teori tentang Penyusunan Tata Kerja dan Analisis Evaluasi. Sedangkan metode kerja individu dan kelompok akan digunakan untuk praktek Penyusunan Tata Kerja dan Analisis Evaluasi di sekolah para peserta pelatihan.

\section{Hasil dan Pembahasan}

Kegiatan pengabdian masyarakat berupa "Pelatihan Penyusunan Tata Kerja dan Analisis Evaluasi Program Kegiatan Sekolah" dilaksanakan dalam bulan Juli di SMK Negeri 1 Kerinci. Sasaran pengabdian ini adalah pimpinan sekolah, guru dan staf di lingkungan sekolah tersebut. Rincian kegiatan ini adalah sebagai berikut:

Tabel 2. Rincian Kegiatan Pengabdian

\begin{tabular}{|c|c|c|c|c|c|}
\hline No & $\begin{array}{l}\text { Tankegal } \\
\text { Kegatan }\end{array}$ & Jenis kegiatan & $\begin{array}{l}\text { Jamlah } \\
\text { peserta }\end{array}$ & Hari & Jam \\
\hline & 6 April 2020 & Survey & 5 & Senin & 09.00 \\
\hline 2. & 23 Jull 2019 & $\begin{array}{l}\text { Sosialisasi Program dengan } \\
\text { Kepala Sekolah SMK Niegeri I } \\
\text { Kerinci dan guru / peserta } \\
\text { kegiatan. }\end{array}$ & 30 & Kamis & 10.00 \\
\hline 3. & 24 Jull 2020 & $\begin{array}{l}\text { Penyusunan Tata Kerja dan } \\
\text { Analisis Evaloani Program } \\
\text { Kegiatan Sekolah di SMK Negeri } \\
\text { I Kabupaten Kerinci }\end{array}$ & 30 & Jumnt & $03.00-16.10$ \\
\hline 4. & 27 Juli 2019 & $\begin{array}{l}\text { Evaluasi pelaksanaan kegiatan } \\
\text { pelatihan }\end{array}$ & 30 & Senin & $08.00-10.00$ \\
\hline
\end{tabular}

Tata kerja merupakan hal yang sangat penting bagi setiap organisasi, termasuk sekolah sebagai lembaga pendidikan. Untuk itulah, pelatihan tata kerja ini dilaksanakan agar para pimpinan, guru dan staf dapat memahami tugas pokok dan fungsinya di sekolah termasuk bagaimana alur kerja yang baik dan benar. Ghani (2014:8) mengemukakan bahwa sebagai lembaga pendidikan, sekolah dituntut untuk terus berbenah dengan mengembangkan manajemen tata kelola sekolah yang baik. Tata sekolah yang baik menjadi prasyarat bagi keberhasilan suatu proses pendidikan yang dijalankan sekolah tersebut, dan pada akhirnya akan member kontribusi yang signifikan bagi pengembangan sumber daya manusia yang berkualitas. Tata sekolah yang baik akan memberi ruang dan kesempatan yang proporsional kepada para siswa untuk mengembangkan potensi mereka secara optimal.

Materi pertama berupa Pelatihan Penyusunan Tata Kerja Sekolah merupakan sebuah pengantar bagaimana cara mengelola sekolah yang baik. Mengelola sekolah sebagai 
suatu lembaga pendidikan tentu saja perlu merujuk pada peraturan yang berlaku serta memiliki suatu panduan pelaksanaan dalam bentuk SOP (Standar Operasional Prosedur). Adanya materi Pelatihan Penyusunan Tata Kerja Sekolah diharapkan dapat membuka wawasan pimpinan sekolah mengenai pengelolaan sekolah secara baik dan benar. Pengelolaan yang baik dapat meningkatan kualitas dan daya saing sekolah, terutama sekolah kejuruan yang biasanya dianggap sebagai sekolah "kelas dua" yang tertinggal dari sekolah umum yang dianggap lebih modern. Materi Pelatihan Penyempurnaan SOP Sekolah merupakan penunjang bagi materi sebelumnya. SOP merupakan sesuatu yang sangat penting karena merupakan sebuah panduan kerja yang harus dilaksanakan oleh semua stakeholder sekolah dari tingkat pimpinan, guru, staf bahkan bagian terkecil dari sekolah tersebut.

Materi terakhir berupa Pelatihan Evaluasi Program Kegiatan Sekolah merupakan hal yang sangat penting dilakkan untuk melihat sejauh mana penilaian terhadap programprogram kegiatan sekolah. Evaluasi perlu dilaksanakan sehingga ada sebuah terobosan terhadap program-program yang ada dan juga usulan program-program yang baru. Evaluasi merupakan suatu bagian terpenting dalam manajemen sekolah yang terdiri dari POAC (Planning, Organizing, Actuating, Controlling). Diharapkan dengan adanya evaluasi maka ada perbaikan dan pembaharuan dari program-program kegiatan sekolah yang telah dilaksanakan serta ada usulan baru untuk program-program yang belum ada.

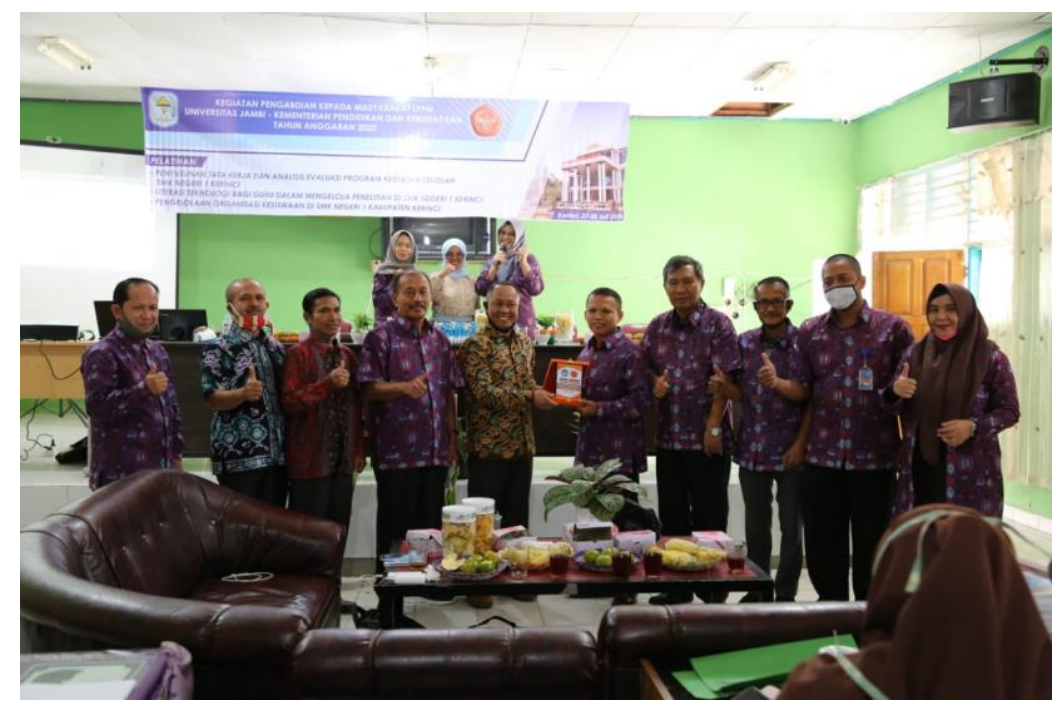

Gambar 1. Kegiatan Pengabdian

Penyusunan alur Tata Kerja berkaitan dengan pembuatan SOP yang akan dijalankan. Tujuan pembuatan SOP adalah untuk menjelaskan perincian atau standar yang tetap mengenai aktivitas pekerjaan yang berulang-ulang yang diselenggarakan dalam suatu organisasi. (Hartatik, 2014:30). SOP yang baik adalah SOP yang mampu menjadikan arus kerja yang lebih baik, menjadi panduan untuk anggota baru, penghematan biaya, memudahkan pengawasan, serta mengakibatkan koordinasi yang baik antara bagianbagian di dalam organisasi. Sementara fungsi SOP adalah sebagai berikut:

1) Memperlancar tugas petugas/pegawai atau tim/unit kerja.

2) Sebagai dasar hukum bila terjadi penyimpangan. 
3) Mengetahui dengan jelas hambatan-hambatannya dan mudah dilacak.

4) Mengarahkan petugas/pegawai untuk sama-sama disiplin dalam bekerja.

5) Sebagai pedoman dalam melaksanakan pekerjaan rutin.

SOP atau yang sering disebut sebagai prosedur tetap (protap) adalah penetapan tertulis mengenai apa yang harus dilakukan, kapan, dimana dan oleh siapa dan dibuat untuk menghindari terjadinya variasi dalam proses pelaksanaan kegiatan oleh pegawai yang akan mengganggu kinerja organisasi secara keseluruhan. Berdasarkan Permenpan No.PER/21/M-PAN/11/2008 SOP memiliki manfaat bagi organisasi antara lain:

1) Sebagai standarisasi cara yang dilakukan pegawai dalam menyelesaikan pekerjaan khusus, mengurangi kesalahan dan kelalaian.

2) SOP membantu staf menjadi lebih mandiri dan tidak tergantung pada intervensi manajemen, sehingga akan mengurangi keterlibatan pimpinan dalam pelaksanaan proses sehari-hari.

3) Meningkatkan akuntabilitas dengan mendokumentasikan tanggung jawab khusus dalam melaksanakan tugas.

4) Menciptakan ukuran standar kinerja yang akan memberikan pegawai sebagai cara konkret untuk memperbaiki kinerja serta membantu mengevaluasi usaha yang telah dilakukan.

5) Menciptakan bahan-bahan training yang dapat membantu pegawai baru untuk cepat melakukan tugasnya.

6) Menunjukkan kinerja bahwa organisasi efisien dan dikelola dengan baik.

7) Menyediakan pedoman bagi setiap pegawai di unit pelayanan dalam melaksanakan pemberian pelayanan sehari-hari.

8) Menghindari tumpang tindih pelaksanaan tugas pemberian pelayanan.

9) Membantu penelusuran terhadap kesalahan-kesalahan prosedural dalam memberikan pelayanan sehingga menjamin proses pelayanan tetap berjalan dalam berbagai situasi.

Selain sebagai acuan dalam pelaksanaan tugas sehari-hari, penyusunan tata kerja merupakan upaya untuk merencanakan dan mengelola program kegiatan yang diselenggarakan sekolah. Setiap program kegiatan yang direncanakan perlu diakhiri dengan evaluasi yang dimaksudkan untuk melihat kembali apakah program tersebut dilaksanakan sesuai dengan perencanaan dan sesuai dengan tujuannya. Melalui informasi hasil evaluasi, dapat dibandingkan apakah suatu program sesuai dengan kriteria yang telah ditetapkan sebelumnya dan selanjutnya diambil keputusan apakah program akan diteruskan, direvisi, dihentikan karena menimbulkan banyak masalah, atau dirumuskan kembali disesuaikan dengan tujuan, sasaran, dan alternatif baru yang berbeda dengan sebelumnya.

Berkiatan dengan evaluasi program sekolah, dalam bidang pendidikan terdapat dua jenis evaluasi yaitu evaluasi hasil belajar dan evaluasi program pendidikan. Evaluasi hasil belajar bertujuan untuk mengukur apakah pembelajaran berbagai bidang ilmu mencapai tujuan yang ditentukan oleh kurikulum pembelajaran ilmu tersebut. Evaluasi program pendidikan untuk mengevaluasi berbagai aspek pendidikan misalnya kurikulum, proses dan metode pembelajaran mata pelajaran, layanan pendidikan, tenaga pendidik dan 
sebagainya. (Wirawan, 2012:5-7). Keputusan yang dapat diambil berdasarkan hasil evaluasi suatu program, diantaranya (Mahmudi, 2011:119):

1) Menghentikan program, karena dipandang program tersebut tidak ada manfaatnya atau tidak dapat terlaksana sebagaimana yang diharapkan;

2) Merevisi program, karena ada bagian-bagian yang kurang sesuai dengan harapan;

3) Melanjutkan program, karena pelaksanaan program menunjukkan segala sesuatunya sudah berjalan dengan harapan;

4) Menyebarluaskan program, karena program tersebut sudah berhasil dengan baik maka sangat baik jika dilaksanakan lagi di tempat waktu yang lain.

Beberapa hambatan yang muncul dalam upaya penyusunan tata kerja dan analisis evaluasi program kegiatan sekolah antara lain:

1. Hambatan personal, yaitu kurangnya pemahaman mengenai prosedur kerja dan evaluasi kegiatan dari masing-masing warga sekolah.

2. Hambatan organisasi, yaitu kurangnya pemahaman untuk menjabarkan struktur organisasi yang ada.

3. Hambatan manajerial, yaitu pengelolaan organisasi sekolah yang kurang efektif dan efisien.

Ada beberapa manfaat yang dapat diambil dalam penyusunan tata kerja sekolah, antara lain:

1. Mempermudah pimpinan sekolah, guru dan staf dalam menjalankan tugas

2. Tugas-tugas dapat dilaksanakan secara teratur dan tepat waktu

3. Keletihan dalam bekerja dapat diatasi

4. Pekerjaan yang terbengkalai dapat diatasi

5. Tujuan pekerjaan dapat tercapai secara efektif

6. Dapat dilakukan standarisasi dan pengendalian kerja dengan setepat - tepatnya

7. Dapat dijadikan sebagai pedoman kerja

Sedangkan manfaat yang dapat diambil dalam analisis evaluasi program kegiatan sekolah antara lain:

1. Evaluasi program berguna bagi pengambilan keputusan dan kebijakan lanjutan dari program yang dilaksanakan.

2. Menghentikan program, karena dipandang program tersebut tidak ada manfaatnya, atau tidak dapat terlaksana sebagaimana diharapkan.

3. Merevisi program, karena ada bagian-bagian yang kurang sesuai dengan harapan (terdapat kesalahan tapi hanya sedikit).

4. Melanjutkan program, karena pelaksanaan program menunjukan bahwa segala sesuatu sudah berjalan sesuai dengan harapan dan memberikan hasil yang bermanfaat.

5. Menyebarluaskan program, karena program tersebut berhasil dengan baik maka sangat baik jika dilaksanakan lagi di tempat dan waktu yang lain. 


\section{Kesimpulan}

Kegiatan pengabdian ini merupakan pelaksanaan program pengabdian masyarakat (PPM) FKIP Universitas Jambi dalam memberdayakan mitra-mitranya. Sasaran kegiatan ini adalah pimpinan sekolah, guru dan staf di SMK Negeri 1 Kerinci. Program pengabdian dimulai dari pertemuan pendahuluan dilanjutkan dengan pemaparan materi pelatihan dan praktek.

Output yang diharapkan dari kegiatan pengabdian ini antara lain: 1) pimpinan, guru dan staf dapat memyusun tata kerja dalam mengelola program kegiatan sekolah; 2) dirumuskannya SOP sebagai panduan kerja; 3) adanya evaluasi bagi program-program kegiatan sekolah; dan 4) tenaga pendidik dan kependidikan dapat meningkatkan karir dan profesionalitasnya melalui peningkatan kinerja berdasarkan SOP yang ada.

Saran yang dapat diajukan dalam kegiatan ini adalah:

1) Kegiatan ini sangat penting bagi pimpinan, guru dan staf selaku pengelola sekolah dan sebagai sasaran latih dengan pertimbangan bahwa penyusunan tata kerja dan analisis evaluasi program sekolah ini sangat penting dan bermanfaat besar dalam menunjang program kegiatan sekolah.

2) Kegiatan ini idealnya dapat menjangkau seluruh sekolah dalam satu wilayah kabupaten/kota dan dengan fokus latih yang baik dan tentunya harus didukung dengan sarana, prasarana, anggaran dan materi yang ideal

\section{Daftar Pustaka}

Ghani, A.R.A. (2014). Metodologi Penelitian Tindakan Sekolah. Jakarta: Rajawali Pers.

Hartatik, I.P. (2014.) Buku Praktis Mengembangan SDM. Yogyakarta: Laksana.

Laksmi, F dan Budiantoro. (2008). Manajemen Perkantoran Moderen. Jakarta: Pernaka

Lazwardi, D. (2017). Implementasi Evaluasi Program Pendidikan di Tingkat Sekolah Dasar dan Menengah. Al-Idarah: Jurnal Kependidikan Islam Volume VII Nomor II 2017 hal. 142-156.

Mahmudi, I. (2011). CIPP: Suatu Model Evaluasi Program Pendidikan. Jurnal At-Ta'dib Volume 6 Nomor I Juni 2011.

Peraturan Menteri Negara Pendayagunaan Aparatur Negara Nomor PER/21/M.PAN/11/2008 tentang Pedoman Penyusunan Standar Operasional Prosedur (SOP) Administrasi Pemerintahan.

Sailendra, A. (2015). Langkah-langkah Praktis Membuat SOP. Yogyakarta: Trans Idea Publishing

Sudjana, D. (2006). Evaluasi Program Pendidikan Luar Sekolah. Bandung: Remaja Rosdakarya.

Tayipnapis, F.Y. (2008). Evaluasi Prigram dan Istrumen Evaluasi untuk Program Pendidikan dan Penelitian. Jakarta :Rineka Cipta

Warsidi, A. (2000). Administrasi Perkantoran. Jakarta: Waworuntu. 
Wirawan. (2012). Evaluasi: Teori, Model, Standar, Aplikasi dan Profesi. Cetakan kedua. Jakarta: Rajawali Pers. 